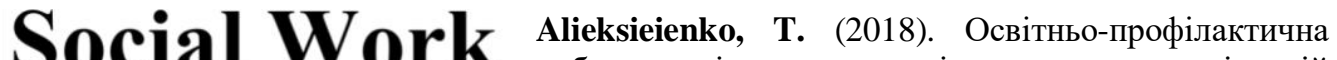
\& Education робота соціального працівника у територіальній громаді: досвід та перспективи, Social Work and Education, Vol. 5, No. 4., pp. 8-18. DOI: $10.25128 / 2520-$ 6230.18.4.1

๑) SW\&E, 2018

Tetiana Alieksieienko,

Doctor of Pedagogical Sciences,

Associate Professor,

Head of social Pedagogy laboratory,

\title{
ОСВІТНЬО-ПРОФІЛАКТИЧНА РОБОТА СОЦАЛЬНОГО ПРАЦІВНИКА У ТЕРИТОРІАЛЬНІЙ ГРОМАДІ: ДОСВІД ТА ПЕРСПЕКТИВИ
}

Institute for Education Problems

National Academy of Pedagogical Sciences of Ukraine

Kyiv, Ukraine

alekseenko.tf@gmail.com

ORCID: 0000-0002-2060-2354

Тетяна Алєкссєнко,

доктор педагогічних наук,

старший науковий співробітник,

завідувачка

соиіальної педагогіки,

Інститут проблем виховання

Національної

академіі

педагогічних наук України

м. Київ, Украӥна

УДК 37.013 .42 : 364.04 [352 : 379.81] (332).

DOI: $10.25128 / 2520-6230.18 .4 .1$

Article history:

Received: October 10, 2018

1st Revision: November 17, 2018

Accepted: December 30, 2018
АНОТАЦІя. У статті, 3 урахуванням сучасних тенденцій i нормативно-правового забезпечення у розвитку освіти та територіальних громад в Україні, зокрема їх децентралізації та об’єднання, розкрито проблему освітньо-профілактичної роботи за участі соціальних працівників, піi стан у нормативно-правовому забезпеченні i на прикладах просвітницьких заходів та соціальних проектів профілактичного змісту, у контексті основних підходів до розв'язання соціальних проблем (на основі надання соціальних послуг; на основі розвитку громади); розкрито зарубіжний досвід реалізації моделі соціальної роботи на основі розвитку громади; іiі інтегративний контент; запропоновано авторське визначення поняття «освітньо-профілактична робота соціального працівника у громаді».

Ключові слова: територіальна громада; освітньо-профілактична робота; соціальні працівники; моделі соціальної роботи; інтеграція; партнерство. 


\section{Вступ}

Складність завдань, пов'язаних 3 процесами децентралізації громад, реформування освіти і водночас розвитком деструктивних соціальних явищ у сучасній Україні актуалізують потребу активізації освітньо-профілактичної роботи та посилення ролі соціальних працівників у мобілізації громад на розв'язання існуючих у них соціально-педагогічних проблем, пов'язаних з навчанням, вихованням, соціальним самопочуттям членів громади. Ці проблеми знаходять відображення в індивідуальній та груповій свідомості, базових цінностях, соціальних очікуваннях і життєвих пріоритетах, проявах культури, моделях поведінки, мірі згуртованості, соціальному становищі дітей, сімей та інших членів громади.

Наразі реформа децентралізації в Україні (яку планується завершити у 2020 році) асоціюється 3 кількістю утворених ОТГ (об’єднання територіальних громад), місцевими бюджетами та органами місцевого самоврядування. На такі маркери орієнтують Закони України «Про добровільне об'єднання територіальних громад» (2015), «Про місцеві вибори» (2015), «Про співробітництво територіальних громад» (2014), Концепція реформування місцевого самоврядування та територіальної організації влади в Україні (2014). У відповідності до кількісних маркерів поки що систематично здійснюється i моніторинг процесу децентралізації влади та реформування місцевого самоврядування. Показники якості життя та підвищення якості надання послуг у громаді визначаються прогностично і ще не стали пріоритетом державної соціальної політики. Їх розробка ускладнюється сучасним станом економіки, інноваційним характером змін та станом розвитку соціальних інституцій в об'єднаних територіальних громадах України.

Високий потенціал у профілактиці негативних соціальних явищ містить реформа освіти, нормативні положення та інноваційні ідеї якої закладено в Закон України «Про освіту» (2017), Концепцію реалізації державної політики у сфері реформування загальної середньої освіти «Нова українська школа» на період до 2029 року (2016), Концепцію розвитку громадянської освіти в Україні (2018) та ін. Ними концептуально визначено орієнтир на формування компетентностей, розробку нових стандартів освіти, розвиток педагогіки партнерства та громадянської освіти як такої, що буде охоплювати всі складники, рівні, види освіти (формальну, неформальну, інформальну), а також всі вікові групи громадян, у тому числі освіту дорослих. Реалізація визначених орієнтирів сприятиме комплексній організації освітньопрофілактичної роботи щодо соціально-педагогічних проблем окремих громад та посиленню в такому процесі ролі соціального працівника. Визначена перспектива актуалізує потребу узагальнення та осмислення вже напрацьованого у цьому досвіду.

\section{Аналіз останніх публікацій.}

До аналізу проблеми діяльності соціального працівника у територіальній громаді дослідники зверталися в різних аспектах, зокрема щодо: соціального партнерства (П.Грінер, А.Колодій, О.Кушнір, М.Скиба, В.Скуратівський, В.Якимець), покращення якості соціальних послуг дітям та сім'ям у громаді, розкриття технологій активізації громади (Т. Алєксєєнко, О. Безпалько, І. Звєрєва, Г. Лактіонова, Ж. Петрочко), узагальнення соціологічних методів в оцінці проблем і потреб членів громади (М. Боп, Д. Боп, Т. Семигіна), соціальної роботи 3 надання соціальних послуг населенню 
(К. Іващенко, І. Козубовська, Г. Слозанська), особливостей соціальної роботи у зарубіжних країнах (Г. Брагер, А. Капська, М. Майо, Ю. Палагнюк, В. Поліщук, П. Тейлор) та інші. Однак, проблема освітньо-профілактичної діяльності соціального працівника у громаді ще не стала предметом спеціального дослідження.

Мета і завдання статті - проаналізувати особливості та сучасний стан освітньопрофілактичної роботи соціальних працівників у територіальних громадах України, розкрити іiі інтегративний контент.

\section{Методологія дослідження}

Основоположними у розумінні соціальних процесів, які відбуваються у громаді, та оцінки ефективності діяльності у громаді соціального працівника визначаються положення соціальної теорії груп, зокрема теорії соціальної структури (Т.Гоббс, Ч.Кулі, Е.Шілз), теорії групи інтересів (А.Бентлі, Г.Алмонд), теорії групової динаміки (М.Шоу), теорії групової дії (М.Олсон), теорії обміну (Дж. Хоманс), ідея поєднання виховних впливів сім'ї, школи і громади (П. Наторп).

В основу методології нашого осмислення проблеми покладаються положення соціальних теорій, а саме: теорії соиіальних систем, яка орієнтує на усвідомлення того, що суспільство як соціальна система складається з цілого ряду інших систем, змінюється у своїх структурних компонентах залежно від ускладнення соціальних функцій, а система дії визначається способом взаємодії з навколишнім середовищем та має відповідати основним функціям - адаптації, наслідування, цільового досягнення, інтеграції (Парсон, 2000); теорії соиіальної дії, яка спрямована на обгрунтування потреби не тільки в осмисленості, усвідомленості соціальної дії, спрямованої на іншого, а й у iï визнанні у виправданих очікуваннях; потреби у практичних рекомендаціях для програм соціальних змін (Вебер, 2006). Наведені концептуальні ідеї теорії соціальної дії знаходять своє підтвердження у фаховій діяльності сучасного соціального працівника як соціально-ціннісної діяльності та актуалізують необхідність iii позитивного підкріплення у суспільній думці; теорії соиіального реалізму яка акцентує увагу на онтології соціальної реальності та обгрунтовує ідеї згуртованості, партнерства і соціальної солідарності (Дюркгейм, 1995). Ідеї общинної педагогіки (за місцем проживання) і «громадського виховання», зокрема щодо ролі найближчого соціального середовища і узгоджених його впливів, створення цілісного виховного середовища у територіальній громаді у соціальному становленні особистості. Основними методами осмислення проблеми обрано концептуальний аналіз емпіричної інформації та проектування.

\section{Основна частина}

Освітньо-профілактична робота у громаді як форма утвердження ціннісного смислу i способу життя здійснюється посередництвом упровадження різноспрямованих тематичних програм і цільових проектів, зміст яких враховує актуальні потреби членів громади, орієнтований на формування у них необхідних компетенцій, а також на вирішення та упередження проблем, які впливають на соціальне самопочуття людини та міру іiі залучення у життя громади. У фаховій діяльності соціальних працівників освітньо-профілактична робота може здійснюватися шляхом надання соціальних послуг. Ї̈̈ ефективність передбачає чітку орієнтацію на 
потреби цільових груп, динаміку їх змін та систематичне підвищення якості соціальних послуг.

У вітчизняному досвіді основними і безпосередніми надавачами соціальних послуг у територіальних громадах визначено територіальні центри соціального обслуговування, центри соціальних послуг, неурядові (громадські) організації. Вони здійснюють послуги у відповідності до існуючих індивідуальних потреб вразливих категорій населення та розроблених індивідуальних планів допомоги, на підставі укладених договорів (між надавачем і отримувачем), а також шляхом внутрішнього моніторингу щодо оцінки їх якості.

Згідно «Типового положення про територіальний центр соціального обслуговування (надання соціальних послуг), який було затверджено постановою Кабінету Міністрів України від 29 грудня 2009 р. (№ 1417) «Територіальний центр утворюється для здійснення соціального обслуговування та надання соціальних послуг громадянам, які потребують сторонньої допомоги, за місцем проживання, в умовах стаціонарного, тимчасового або денного перебування» (Туріcal provision for the territorial center..., 2018).

Структурою Територіального центру соціального обслуговування (надання соціальних послуг) як державної установи передбачено функціонування відділень, основними завданнями яких $є$ надання соціальної і паліативної допомоги вдома громадянам похилого віку, особам з інвалідністю, невиліковно хворим (які не здатні до самообслуговування i потребують сторонньої допомоги), адресної допомоги $\mathrm{i}$ виконання соціальних програм, здійснення соціально-медичної реабілітації.

Зміст діяльності структурних відділень передбачає реалізацію комплексу соціально-побутових, психологічних, інформаційних, соціально-педагогічних та інших соціальних послуг, спрямованих на підтримку життедіяльності і певної соціальної активності осіб, що опинилися у складних життєвих обставинах. У відділеннях паліативної допомоги вдома, які вперше в історії України почали діяти у Печерському районі м. Києва, використовується потенціал мультидисциплінарних команд для забезпечення потреб пацієнтів та їхніх родичів. Паліативна допомога вдома, що надається на базі територіального центру, включає: надання соціально-побутової допомоги соціальним робітником, консультації психолога, надання медичних консультацій і допомоги. У приміщеннях територіального центру 3 клієнтами здійснюються не тільки індивідуальні, а й групові форми роботи. Зокрема проводяться навчання для осіб пенсійного віку, організовується робота кабінету психологічного розвантаження, підтримуються зв'язки із закладами культури й мистецтва для організації дозвілля громадян похилого віку та осіб з інвалідністю (організовуються зустрічі 3 митцями, проводяться заходи 3 нагоди свят і видатних подій, засідання клубів за інтересами), відбуваються індивідуальні та групові заняття з лікувальної фізкультури. До прикладу, у Територіальному центрі соціального обслуговування в Печерському районі м. Києва у відділенні денного перебування в 2016 році організовано надання такої соціально-педагогічної послуги, як «Університет третього віку». В ньому надавалась можливість на більше ніж 10 «факультетах» вивчати основи здоров'я, психологію, мистецтво, хореографію, декоративно-прикладне мистецтво, релігієзнавство, краєзнавство, інформаційні технології, іноземні мови (англійську, німецьку, польську, французьку, іспанську, італійську) тощо. У такий спосіб 
задовольнялись освітні потреби та потреби у духовному розвитку отримувачів соціальних послуг (The official internet portal of the Pechersk District State Administration in Kyiv, 2016). Цей приклад не поодинокий.

Упровадження соціально-педагогічної послуги «Університет третього віку» у всіх районних територіальних центрах соціального обслуговування (надання соціальних послуг) м. Києва здійснюється на виконання наказу Міністерства соціальної політики України «Про впровадження соціально-педагогічної послуги «Університет третього віку» (№ 326 від 25.08.2011). Згідно відомчих інформаційних матеріалів у 2016-2017 навчальному році на 78 факультетах та у 43 гуртках навчалися 2022 особи, значна кількість 3 яких відвідували по кілька факультетів та гуртків одночасно. За навчальний період працівниками територіальних центрів, запрошеними професіоналами та волонтерами проведено 4357 занять (3029 занять на факультетах та 1328 - у гуртках). Найбільшою популярністю користувалися факультети «Інформаційних технологій», «Прикладного та художнього мистецтва» й «Іноземної мови», які запроваджені і функціонують у 8 з 10 територіальних центрах столиці (Department of Social Policy, 2018).

Фахівці відмічають у людей похилого віку велике бажання навчатися. Їх залучення в «Університет третього віку» після виходу на пенсію допомагає в адаптації до нової соціальної ситуації свого життя, у змістовному спілкуванні з іншими, підтримці інтелектуальних здібностей, відкриттю в собі нових талантів, формує в них оптимізм (Bogutska, 2017, p. 103-111).

Аналіз нормативно-методичного забезпечення надання соціальних послуг переконує у державному регулюванні соціальних послуг. Так, Наказом Міністерства соціальної політики (2018р.) затверджено Методичні рекомендації щодо виконання повноважень ОТГ у сфері соціального захисту населення. Структурним підрозділам 3 питань соціального захисту населення обласних державних адміністрацій цим наказом було дано такі завдання: сприяти в упровадженні моделі адміністрування надання соціальних послуг і соціальної підтримки населення у 38 об’єднаних територіальних громадах; забезпечити навчання працівників уповноважених підрозділів (посадовців) пілотних ОТГ шляхом відпрацювання комунікативних навичок, техніки ведення співбесіди, інформування громади про прийняття рішень; здійснювати координацію і взаємодію з партнерами в упровадженні інновацій та інтегрованих соціальних послуг, соціальних мікропроектів; проводити інформаційно-роз'яснювальну роботу серед населення із залученням ЗМІ (2018).

Конкретними прикладами виконання даного наказу сприймаються вже проведені у територіальних громадах просвітницькі заходи та соціальні проекти профілактичного змісту. Так, у грудні 2017 року в ході виконання проекту «Розробка концепції та функціонально-структурної моделі інтегрованої системи соціального захисту в Україні (реалізується Oxford Policy Management (UK) та МБО «Партнерство «Кожній дитині» за підтримки Дитячого фонду ООН ЮНІСЕФ), відбувся семінар, де розглядались питання повноважень ОТГ щодо соціального захисту населення та захисту прав дітей, ролі сімейно-оріснтованого підходу, механізмів соціального планування, основних характеристик, базових параметрів моделі ICC3Н, технології кейс-менеджменту в соціальній роботі й інше. 
За ініціативою U-LEAD (Програма «U-LEAD з Свропою») та за участю Міжнародної благодійної організації «Партнерство «Кожній дитині» започатковано проект для об’єднаних територіальних громад «Громада для людини: підвищення компетентності громад для розвитку соціальних послуг» (листопад 2018 - серпень 2019) з метою підготовки керівників та спеціалістів соціальної сфери у запровадженні моделі інтегрованих соціальних послуг для вразливих категорій громади та підвищення відповідальності за їхню безпеку і благополуччя. Згідно комплексної програми передбачено навчання і консультування фахівців у питаннях соціального захисту та сфери соціальних послуг, обмін досвідом та кращими практиками у запровадженні інноваційних методик та технологій соціальної роботи (Every Child's Partnership, 2018).

3 метою надання вчасної та якісної (адекватної до потреб) адресної допомоги членам громади, у листопаді 2018 року було презентовано пілотний проект «Міждисциплінарний підхід з надання соціальних послуг громадам Рівненщини». Ним передбачається налагодження партнерства у системі «держава - бізнес - громада». Згідно проекту розробляються «Карти соціальної спроможності громад». У подальшому вони слугуватимуть підставою як для об’єктивної оцінки потреб громади, так i для оцінки ОТГ за параметром надання соціальних послуг (RadioTrek). Наведені приклади, а також аналіз інформації, розміщеної на сайтах територіальних громад та звітної відомчої документації соціальних служб різних рівнів свідчить про розгортання освітньо-профілактичної роботи (The social project of OTG..., 2018).

Водночас загальна оцінка реальної ситуації щодо стану соціальної роботи в територіальних громадах вказує на певні проблеми і тенденції, а саме:

- відбувається скорочення мережі існуючих територіальних центрів соціального обслуговування;

- соціальних працівників включають до штату виконкомів об'єднаних територіальних громад;

- реформування територіальних громад в Україні певною мірою супроводжується розробленням методичного інструментарію на активізацію в них соціальної роботи, іiі здійснення у відповідності до державних стандартів;

- як домінуюча, в Україні відпрацьовується модель адміністрування надання соціальних послуг і соціальної підтримки населення в об'єднаних територіальних громадах, зовнішнього керування освітньо-профілактичною роботою.

Між тим, у міжнародній практиці соціальної роботи в громадах диференційовано два основні підходи до розв'язання соціальних проблем:

1) на основі надання соціальних послуг;

2) на основі розвитку громади (Ворр \& Ворp, 1998, 28).

Їх принципова різниця виявляється в тому, що за першого підходу рішення, ініціативи щодо різних заходів і різних груп потребуючих осіб надходять 3зовні, від інших (напр.: державних інституцій, громадських організацій). Вони, зазвичай, пов'язані з соціальною політикою, реформами та упровадженням соціальних проектів), за другого - ініціюються зсередини, від членів громади (зазвичай спрямовуються на поліпшення благоустрою громади, організацію способу іiі життя і дозвілля, підтримку нужденних членів громади; виявляються у фактах кризового втручання). Успішний досвід реалізації моделі соціальної роботи на основі розвитку громади знаходимо у 
зарубіжному досвіді і в першу чергу у тих країнах, які вирізняються стабільністю у захисті своїх цінностей і культурних надбань. Освітньо-профілактична робота в них здійснюється 3 урахуванням традицій інтеграційної взаємодії батьків, учителів, представників громадських організацій та місцевих органів управління.

Проте, реальна практика переконує і в тому, що позитивні зміни найбільшою мірою досягаються за умови використання двох підходів. Як справедливо стверджував Ф.Тейлор, жоден із соціальних інститутів не є досконалим, тому, з одного боку, потребує допомоги інших, а з іншого - може компенсувати взаємні недоліки і невдачі (Taylor, 2010).

Також необхідне розуміння того, що ефективність соціальної і соціальнопедагогічної роботи у громаді також значною мірою залежить від врахування іiі внутрішньої структури: наявності та функціонування різних соціальних інститущій (управлінські органи, заклади освіти різних рівнів і форм власності, заклади культури, виробничі установи, заклади сфери обслуговування, соціальні служби і центри, неурядові організації тощо); невеликих згуртувань за інтересами (школярі, молодь; інтелігенція; молоді сім'ї; члени клубів і гуртків; прихожан та інших); соціальних груп зі специфічними потребами (одинокі, пенсіонери, особи з інвалідністю, діти-сироти, неповні сім'ї та інших). А також їх активності - всі ці інституції і неформальні малі громади $\epsilon$ суб'єктами територіальної громади, мають здатність до відтворення або творчого вияву соціальної активності, спрямованої на задоволення потреб як громади в цілому, так і окремих іiі членів.

3 урахуванням сучасних соціально-виховних викликів посилюється потреба більш активного залучення батьків до спільної із закладами освіти і культури виховної діяльності з дітьми, правової просвіти батьків, надання батькам допомоги у сімейному вихованні дитини, спільної організації соціального захисту дітей, утвердження здорового способу життя сімей, молоді, громади в цілому тощо.

Нам імпонуе думка Т. Парсонса про те, що відносини партнерства, які виникають між суб'єктами соціальної взаємодії, ініціюють розвиток нового типу відносин (Parsons, 2000, 256).

Освітньо-профілактична діяльність у громаді потребує здійснення на різних рівнях:

- робота 3 дітьми (сприяння в їх соціалізації через систему соціальнокультурних заходів, в соціальній інтеграції у життя громади, розвиток активності);

- робота серед дорослого населення шляхом їх залучення в активне громадське життя і в різні форми освіти;

- активізація діяльності дорослого населення громади у вихованні молоді та поліпшенні життя в громаді.

Така ідея закладена нами в авторську «Концепцію соціально-педагогічної підтримки сім'ї та сімейного виховання у місцевих громадах». В ній визначається, що стратегічна мета соціально-педагогічної підтримки полягає в активізації громади у розв'язанні іiі актуальних соціально-педагогічних проблем, наданні допомоги сім'ям i дітям груп соціального ризику, об'єднанні у подоланні дитячої злочинності і злочинів проти дітей, оптимізації функції соціального контролю громади за процесом соціалізації особистості, профілактиці беззмістовного дозвілля батьків дітей i порушень громадського спокою, розбудові цілісного виховного середовища дитини на 
засадах інтеграції виховних сил різних соціальних інституцій, розвитку традицій добросусідства (Alieksieienko, 2017, 52).

Освітньо-профілактична діяльність у громаді потребує розвитку і активного використання ресурсного потенціалу громади (освітніх і культурних закладів дошкільного закладу, школи, музеїв, бібліотеки, спортивних секцій, різних центрів і служб) та застосування інтерактивних форм роботи (утворення груп взаємопідтримки, клубів за інтересами, арт-студій, творчих майстерень, просвітницьких тренінгів, майстер-класів, бізнес-проектів і соціальних проектів, ігор і змагань, доброчинних акцій, організація масових просвітницьких акцій за різною тематикою тощо).

В умовах створення цілісності, і це підтверджується на прикладі демократичних суспільств (країн Європейського союзу, США, Канади), інтеграційний контент соціальної та соціальної і соціально-педагогічної роботи в громадах стає наскрізним. Завдяки чому змінюються самі компоненти, що входять до структури цілого (сім'я, школа, малі громади), з'являється нова інтегративна якість (яка знаходить відображення у сучасних тенденціях розвитку територіальної громади і активності іiі членів). Також з'являються нові властивості інтеграції як цілісності, i вони визначаються іï особливими інтегративними зв'язками, побудованими на: спільності цілей, балансі інтересів, прозорості та зрозумілості інформації, ii доступності для всіх учасників взаємодії, прозорості діяльності, публічній звітності, систематичному інформуванні громадськості про досягнуті результати та заплановані дії (шляхом оприлюднення різних видів інформаційних продуктів), обов'язковості, однакової відповідальності сторін за виконання добровільно ухвалених рішень, спрямованості на задоволення освітніх потреб, відкриття перспектив професійного зростання соціальних працівників, цивілізоване вирішення спірних питань і конфліктів.

\section{Висновки}

За нашим уявленням, осмислення сучасного стану розвитку територіальних громад та стану освітньо-профілактичної роботи в них відкриває нові можливості для соціальної педагогіки і соціальної роботи як у науковому, так і в практичному відношенні, зокрема щодо проведення спеціальних досліджень 3 метою виявлення й обгрунтування закономірностей і механізмів складних інтеграційних процесів у житті спільнот, можливостей забезпечення суспільних інтересів в освіті і через освіту, особливостей імплементації принципу партнерства у громаді, створення «соціальних коаліцій» у реалізації освітніх реформ і профілактиці негативних соціальних явищ, розроблення та упровадження технологій активізації громади.

\section{Література}

Алєксєєнко Т. Ф. (2017). Концепція соціально-педагогічної підтримки сім’ї та сімейного виховання у місцевих громадах / Соціально-педагогічна підтримка дітей та учнівської молоді: монографія / [Алєксєєнко Т. Ф., Жданович Ю. М., Малиношевський Р. В. та ін.] / за заг. ред. Т. Ф. Алєксєєнко. К. : ТОВ “Задруга”, 49-66.

Алєксєєнко Т. Ф. (2004). Технології соціально-педагогічної роботи в територіальній громаді. Соціальна педагогіка: теорія та практика, № 2, 19-24.

Богуцька, А. (2017). Принципи організації університету третього віку у Великобританії. Соціальна робота та освіта, 4 (1), 103-111. 
Bopp M., Bopp G. A. (1998). Practical Guide to Building Sugtainable Communities. Calgary: Alberta, 28.

Вебер М. (2006). Поняття соціології та «сенсу» соціальної дії // Загальна соціологія. Хрестоматія / Упоряд. А.Г. Здравомислов, Н.І. Лапін; Пер. В.Г. Кузьмінов; За заг. ред. Н.І. Лапіна, 783.

Департамент соціальної політики. Офіційний інтернет-портал. https://dsp.kyivcity.gov.ua/; $\quad$ https://dsp.kyivcity.gov.ua/content/socialni-poslugy-yakinadayutsya-terytorialnymy-centramy-socialnogo-obslugovuvannya.html.

Дюркгейм Э. (1995). Социология и социальные науки. Социология. Ее предмет , метод , предназначение. М.: Канон, 349.

Парсонс Т. 2000 (1945). Современное состояние и перспективы систематической теории в социологии // О структуре социального действия. М. Академический Проект, $381-414$.

Партнерство «Кожній дитині». Міжнародна благодійна організація. Офіційний сайт: http://www.p4ec.org.ua/ua/news article/1297

Про деякі питання діяльності об'єднаної територіальної громади щодо соціальної підтримки населення та захисту прав дітей. Наказ Міністерства соціальної політики України № 890 від 14 червня 2018 року. Режим доступу: https://www.msp.gov.ua/news/15452.html.

Про добровільне об’єднання територіальних громад : Закон України (2015) // Урядовий кур'єр, 2016, 01, 16.01.2016 N 9.

Типове положення про територіальний центр соціального обслуговування (надання соціальних послуг). Режим доступу: Урядовий портал: https://www.kmu.gov.ua/npas/243237372

У Рівненській області реалізується соціальний проект ОTG. Новини від 23.11.2018. Офіційний сайт Рівненської обласної державної адміністрації. Режим доступу: www.rv.gov.ua/sitenew/main/ua/news/detail/55534.htm.

Щодо діяльності Київського міського та районних територіальних центрів соціального обслуговування (надання соціальних послуг). Офіційний інтернет-портал Печерської районної в місті Києві Державної адміністрації. Режим доступу: tcpechersk@ukr.net. 


\section{EDUCATIONAL-PREVENTIVE WORK IN THE TERRITORIAL COMMUNITY: EXPERIENCE AND PERSPECTIVES}

Tetiana Alieksieienko, Doctor of Pedagogical Sciences, Associate Professor, Head of Social Pedagogy laboratory, Institute for Education Problems National Academy of Pedagogical

Sciences of Ukraine, alekseenko.tf@gmail.com

Abstract. In the article, we tried to show the current trends in the implementation of reforms in the education and decentralization of territorial communities in Ukraine, their normative, legal and methodological support, the problem of educational and preventive work with the participation of social workers as direct providers of social services is revealed, its orientation to meet the existing individual needs of vulnerable categories members of the community, including the functioning of the branches of the Territorial Center of Social Services; Specific examples of educational measures and social projects of preventive maintenance of non-governmental organizations are presented, they are analyzed in the context of the basic approaches to solving social problems (on the basis of providing social services, on the basis of community development); the author's definition of the concept of "educational and preventive work of a social worker in the community" is proposed; the current problems and modern tendencies the state of social work in the territorial communities of Ukraine are determined, and the model of administration of provision the social services as a dominant one is included; the task of development of partnership as a mechanism of development of a new type of community relations in the community, integration of educational forces of the school, family and community on improving the quality of social services, including through community-based educational and preventive work, was actualized; the levels of organization of educational and preventive work in the community and its resource support have been designed.

Key words: territorial community; educational and preventive work; social workers; models of social work; integration; partnership.

\section{References}

Alieksieienko, T.F. (2017). Concept of social-pedagogical support of family and family education in local communities / T.F. Alieksieienko / Social-pedagogical support for children and students: monograph / [Alieksieienko T.F., Zhdanovich Yu.M., Malinoshevsky R.V. etc. ] / per community Ed. T.F. Alieksieienko. K.: LLC "Zadruha", 49-66. [in Ukrainian].

Alieksieienko, T.F. (2004). Technologies of social and pedagogical work in the territorial community. Social pedagogy: theory and practice. 2, 19-24. [in Ukrainian].

Bogutska, A. (2017). Organization principles of the university of the third age in the UK. Social work and education, 4(1), 103-111. [in Ukrainian].

Bopp M., Bopp G. (1998). A Practical Guide to Building Sustainable Communities. Calgary : Alberta. 68 p. [in Canada].

Weber M. (2006). Concept of sociology and "sense" of social action / General sociology. Book / order. : AG Zdravomyslov, NI Lapin per. VG Kuzminov; per community Ed. NO. Lapina - M.: Higher. Shk. 783 p. [in Germany]. 
Department of Social Policy (2018). Official internet portal. https://dsp.kyivcity.gov.ua/; $\quad$ https://dsp.kyivcity.gov.ua/content/socialni-poslugy-yakinadayutsya-terytorialnymy-centramy-socialnogo-obslugovuvannya.html [in Ukrainian].

Durkheim E. (1995). Sociology and Social Sciences / Durkheim E. // Sociology. Her subject, method, purpose. - M.: Canon, 1995. - 349 pp. [in France].

On some issues of the activity of the united territorial community regarding social support of the population and protection of the rights of children. (2018). Order of the Ministry of Social Policy of Ukraine No. 890 dated June 14, Access mode: https://www.msp.gov.ua/news/15452.html. [in Ukrainian].

On Voluntary Association of Territorial Communities: The Law of Ukraine (2015) // Uriadovy Courier, 2016, 01, 16.01.2016 N 9. [in Ukrainian].

Parsons, T. (2000). Current state and perspectives of systematic theory in sociology. On the structure of social action. Moscow: Academic Project, 2000 (1945). 381-414.

Partnership "Every Child". International Charitable Organization (2018). Official site: http://www.p4ec.org.ua/ ua/news_article/1297. [in Ukrainian].

Regarding the activity of Kyiv city and district territorial centers of social services (provision of social services). The official internet portal of the Pechersk District State Administration in Kyiv. Access mode: tcpechersk@ukr.net. [in Ukrainian].

The social project of OTG is being implemented in Rivne region. (2018). News from 11/23/2018. Official site of Rivne Oblast State Administration. Access mode: www.rv.gov.ua/sitenew/main/ua/news/detail/55534.htm. [in Ukrainian].

Typical provision for the territorial center of social services (provision of social services) (2018). Access mode: Government portal: https://www.kmu.gov.ua/npas/243237372. [in Ukrainian]. 